\title{
Effect of Phytohormones and Plant Growth Promoting Microorganisms on Germination and Plant Growth of Aonla (Emblica officinalis Gaertn.)
}

\author{
Vibha Kumari*, Vijay Bahadur, Saket Mishra, Samir Ebson Topno and Deena Wilson
}

Department of Horticulture, Sam Higginbottom University of Agriculture, Technology and Sciences, Prayagraj, India

*Corresponding author

\section{A B S T R A C T}

\section{Keywords}

$\mathrm{GA}_{3}$ (Gibberellic acid),

NAA(Naphthalene

acetic acid),

Aspergillus,

Pseudomonas \&

Photosynthetic

bacteria

Article Info

Accepted:

04 October 2020

Available Online:

10 November 2020
The present experiment was carried out during July 2019 to March 2020 in horticulture research farm of Department of Horticulture, SHUATS, Prayagraj. The experiment was conducted in Randomized Block Design with $13+1$ (control) treatment replicated thrice. The phyto-harmones $\left(\mathrm{GA}_{3}\right.$ and NAA) and plant growth promoting microorganisms (Aspergillus niger, Pseudomonas fluorescens and Photosynthetic bacteria (Rhodopseudomonas palustris) were used as treatments at different concentrations. From the present investigation it is found that treatment $T_{12}$ [Pseudomonas fluorescens + PSB Rhodopseudomonas palustris $(10 \mathrm{ml}$ each in $100 \mathrm{ml}$ distilled water)] was found superior in terms of early germination, seedling length, plant spread, shoot length and chlorophyll content of leaves.

\section{Introduction}

Aonla (Emblica officinalis Gaertn.) is one of the important minor fruit crops of our country. In India, it is known by various names such as Aonla, Amla, Amlika, Dhotri, Emblica and Usuri.

Aonla is a highly nutritious fruit and rich source of vitamin $\mathrm{C}$ and also a fair source of minerals particularly iron, phosphorus, calcium and magnesium. It is also the richest source of pectin which is mostly useful in making jam and jellies. It is also used in tannin and dyeing industries.

The area under Aonla is increasing day by day due to its popularization as a medicinal plant (coolant, refrigerant, diuretic and laxative) and also its potential for better adaptation to diversified soil and climatic conditions. There is great demand for genuine true-to-type planting materials in order to optimize production of quality fruits. 
Biofertilizers plays an important role in the growth of the seedlings. Use of biofertiizers like Aspergillus and Pseudomonas enhance the quality and promote growth without deteriorating the soil and produces quality yield. The growth regulators like $\mathrm{GA}_{3}$ and NAA have been widely used for pre-sowing seed treatments to increase germination and to accelerate vegetative seedling growth.

Application of plant growth regulators in seedling germination of Aonla has become powerful tool to modify several physiological processes in plants which are extensively and profitably used in horticultural crops. They are also used for increasing plant growth and protecting the nursery plants from several insect-pest and diseases.

All plant-related habitats contain a high proportion of plant beneficial microorganisms, plant pathogens and potential human pathogens. The dynamic changes in these micro-organisms may affect sustainable plant production and plant health (Berg et al., 2005; Mendes et al., 2013). In general, plants drive the composition and structure of rhizosphere bacterial communities through root exudates (Bais et al., 2006; Micallef et al., 2009). In turn, rhizosphere microorganisms can promote the overall health of plant species by promoting crop growth and participating root surface defence protection (Berg et al., 2005; Mendes et al., 2013).

\section{Materials and Methods}

The area of Prayagraj district of Uttar Pradesh comes under subtropical belt, which experience extremely hot summer and fairly cold winter. The maximum temperature of the location reaches up to $46^{\circ} \mathrm{C}-48^{\circ} \mathrm{C}$ and seldom falls as low as $4^{\circ} \mathrm{C}-5^{\circ} \mathrm{C}$. The relative humidity (RH) ranges between 20 to $94 \%$. The average rainfall in this area is around $1013.4 \mathrm{~mm}$ annually However, occasional precipitation is also not uncommon during winter months.

The present investigation was carried out on the "Effect of phyto-harmones and plant growth promoting microorganisms on germination and plant growth of Aonla (Emblica officinalis Gaertn.)" under Prayagraj agro-climatic conditions. The experiment was conducted in Randomized Block Design (RBD) with one control and thirteen treatments and three replications at the Research Farm of Department of Horticulture. Total number of treatments was $13+1$ (control).

\section{Treatment details}

The experiment design was RBD and there were fourteen treatments $(13+1)$ which are replicated thrice. The treatment details are $\mathrm{T}_{0}$ (control), $\mathrm{T}_{1}\left(\mathrm{GA}_{3} 100 \mathrm{ppm}\right), \mathrm{T}_{2}\left(\mathrm{GA}_{3} 200\right.$ ppm), $\mathrm{T}_{3}\left(\mathrm{GA}_{3} 300 \mathrm{ppm}\right), \mathrm{T}_{4}$ (NAA $\left.100 \mathrm{ppm}\right)$, $\mathrm{T}_{5}$ (NAA $200 \mathrm{ppm}$ ), $\mathrm{T}_{6}$ (NAA $300 \mathrm{ppm}$ ), $\mathrm{T}_{7}$ [Aspergillus niger $(10 \mathrm{ml} / 100 \mathrm{ml}$ of distilled water)], $\mathrm{T}_{8}$ [Pseudomonas fluorescens $(20 \mathrm{ml} /$ $100 \mathrm{ml}$ of distilled water)], $\mathrm{T}_{9}$ [Photosynthetic Bacteria Rhodopseudomonas palustris (10ml/ $100 \mathrm{ml}$ of distilled water)], $\mathrm{T}_{10}$ [Aspergillus niger + Pseudomonas fluorescens $(10 \mathrm{ml}$ each in $100 \mathrm{ml}$ distilled water)], $\mathrm{T}_{11}$ [Aspergillus niger + PSB Rhodopseudomonas palustris (10ml each in $100 \mathrm{ml}$ distilled water)], $\mathrm{T}_{12}[$ Pseudomonas fluorescens + PSB Rhodopseudomonas palustris $(10 \mathrm{ml}$ each in $100 \mathrm{ml}$ distilled water)], $\mathrm{T}_{13}$ [Aspergillus niger + PSBRhodopseudomonas palustris + Pseudomonas fluorescens ( $(10 \mathrm{ml}$ each in 100 $\mathrm{ml}$ distilled water)]. The aonla seeds were soaked in each treatment for 12 hours and followed by 5 hours of shade drying.

Seeds were grown in polybags filled with soil, sand and FYM in the ratio 2:1:1, respectively. Data were recorded on various growth parameters. 


\section{Results and Discussion}

The data recorded on germination and various growth parameters during 2019-2020, the course of investigation have been presented in Table 1.

The effect of phyto-hormones and plant growth promoting micro-organisms on day of germination of Aonla is very obvious and consistent. There was significant difference among the different treatments at 45, 90, 135,180 and 225 days. The results of the experiment are summarized below.

\section{Day of germination}

The minimum number of days taken for the germination was recorded in $\mathrm{T}_{12}$ [Pseudomonas fluorescens + PSB Rhodopseudomonas palustris $(10 \mathrm{ml}$ each in $100 \mathrm{ml}$ distilled water)] with 6.66 days followed by $\mathrm{T}_{13}$ [Aspergillus niger+ $\mathrm{PSB}$ Rhodopseudomonas palustris + Pseudomonas fluorescens (10 $\mathrm{ml}$ each in 100 $\mathrm{ml}$ distilled water)] with 8.33 day. The maximum number of days was observed in control, which took 24 days for initiation of germination.

Even under the most favourable condition the seed germination in Aonla did not attain its maximum, due to the internal condition namely physiological or biochemical factors. Biofertilizers play a prime role in order to overcome causes controlled by chemical or physiological factors. This finding correlates the findings of Nehal M. Elekhtyar (2015) in rice and I. Ketut Widnyana and Cokorda Javandira (2016) in tomato.

\section{Germination percentage}

The effect of phyto-hormones and plant growth promoting micro-organism on germination percentage of Aonla is very clear. The maximum germination percentage was recorded in $\mathrm{T}_{12}$ [Pseudomonas fluorescens + PSB Rhodopseudomonas palustris $(10 \mathrm{ml}$ each in $100 \mathrm{ml}$ distilled water)] with $72.667 \%$ followed by $\mathrm{T}_{13}$ [Aspergillus niger+ PSB Rhodopseudomonas palustris + Pseudomonas fluorescens $(10 \mathrm{ml}$ each in $100 \mathrm{ml}$ distilled water)] with 70.33 which were significantly superior over control with 33.33 germination percentage.

Seed Germination\% increasedby the favourable effect of PGPR (Plant Growth Promoting Rhizobacteria) might be due to Rhizobacteria traits and could prove effective in improving the seed germination rate. (Malleswari and Bagyanarayana 2013) and (Siva Kumar et al., 2012).

\section{Survival percentage}

The maximum survival percentage was recorded in $\mathrm{T}_{12}$ [Pseudomonas fluorescens+ PSB Rhodopseudomonas palustris $(10 \mathrm{ml}$ each in $100 \mathrm{ml}$ distilled water)] with $69.00 \%$ followed by $\mathrm{T}_{13}$ [Aspergillus niger+ PSB Rhodopseudomonas palustris + Pseudomonas fluorescens $(10 \mathrm{ml}$ each in $100 \mathrm{ml}$ distilled water)] with $66.67 \%$ which were significantly superior over control with $30.33 \%$ survival percentage.

Applications of these associations have been investigated in maize, wheat, oat, barley, peas, canola, soy, potatoes, tomatoes, lentils, radicchio and cucumber (Gray andSmith, 2005).

\section{Shoot length}

Among the treatments applied, $\mathrm{T}_{12}$ [Pseudomonas fluorescens + PSB Rhodopseudomonas palustris $(10 \mathrm{ml}$ each in $100 \mathrm{ml}$ distilled water)] with $25.66 \mathrm{~cm}$ increase significantly better shoot length followed by $\mathrm{T}_{13}$ [Aspergillus niger+ PSB 
Rhodopseudomonas palustris + Pseudomonas fluorescens $(10 \mathrm{ml}$ each in $100 \mathrm{ml}$ distilled water)] with $25.03 \mathrm{~cm}$ which was significantly superior over control with shoot length $19.13 \mathrm{~cm}$.

The increase in height of plant with application of $\mathrm{T}_{12}$ (Pseudomonas + PSB) treatment might be due to its stimulating effect for rapid growth or early seedling growth resulted in more cell division and elongation due to a secretion of IAA by bacteria leading to longest shoot because of the capability of bacteria for fixing nitrogen from air and enhanced metabolism process resulted in more energy and growth improvement.

This finding correlates the findings of Khalimi et al., (2012), Vijay Kumar et al. (1991) in guava and Pawshe et al., (2007) in Aonla.

\section{Plant spread}

The maximum plant spread was recorded in $\mathrm{T}_{12} \quad$ [Pseudomonas fluorescens+ PSB Rhodopseudomonas palustris $(10 \mathrm{ml}$ each in $100 \mathrm{ml}$ distilled water)] with $25.90 \mathrm{~cm}$ followed by $\mathrm{T}_{13}$ [Aspergillus niger $+\mathrm{PSB}$ Rhodopseudomonas palustris + Pseudomonas fluorescens $(10 \mathrm{ml}$ each in $100 \mathrm{ml}$ distilled water)] with $24.63 \mathrm{~cm}$ and the minimum was recorded in control with $17.20 \mathrm{~cm}$.

Vigorous shoot growth due to PGPR might have resulted into increase in production of photosynthates; their translocation through phloem to the root zone might be responsible for increasing the plant spread because of cell multiplication and cell elongation at faster rate. Phyto-harmones promote the plant growth, thought to include the ability to produce auxins (Shaharoona et al., 2006; Egamberdiyeva, 2007; Gholami et al., 2009; Son et al., 2014).

\section{Girth of the seedling}

The observations which were recorded during the experiment period on the effect of phytohormones and plant growth promoting microorganisms on girth of Aonla seedling is that the maximum girth of seedling was recorded in $\mathrm{T}_{12}$ [Pseudomonas fluorescens+ PSB Rhodopseudomonas palustris $(10 \mathrm{ml}$ each in $100 \mathrm{ml}$ distilled water)] with $6.00 \mathrm{~mm}$ followed by $\mathrm{T}_{13}$ [Aspergillus niger + PSB Rhodopseudomonas palustris + Pseudomonas fluorescens $(10 \mathrm{ml}$ each in $100 \mathrm{ml}$ distilled water)] with $5.36 \mathrm{~mm}$ and the minimum was recorded in control with $2.13 \mathrm{~mm}$.

Phyto-harmones increased girth of stem which might be due to stimulation of cambium and its immediate cell progeny by the process of enhancing the rate of cell multiplication. The rate of increase in the dimension of the cell both in pith and cortex region is faster as rather than number of cells per unit area. This type of result was also observed by Das and Pattanaik (2013) in okra. PGPR promote the plant growth, thought to include the ability to produce auxins (Shaharoona et al., 2006; Egamberdiyeva, 2007; Gholami et al., 2009; Son et al., 2014).

\section{Seedling vigour index}

The maximum seedling vigor index was recorded in $\mathrm{T}_{12}$ [Pseudomonas fluorescens+ PSB Rhodopseudomonas palustris $(10 \mathrm{ml}$ each in $100 \mathrm{ml}$ distilled water)] with 2060.53 followed by $\mathrm{T}_{13}$ [Aspergillus niger + PSB Rhodopseudomonas palustris + Pseudomonas fluorescens $(10 \mathrm{ml}$ each in $100 \mathrm{ml}$ distilled water)] with 1912.67 which were significantly superior over control with 713.33 seedling vigor index.

Seedling vigor index $=$ germination percentage $\mathrm{x}$ seedling length (root length+ shoot length) 
Table.1 Effect of different treatments on growth parameters of Aonla

\begin{tabular}{|c|c|c|c|c|c|c|c|c|c|c|}
\hline Notation & Treatment combination & $\begin{array}{l}\text { Day of } \\
\text { germination }\end{array}$ & $\begin{array}{l}\text { Germination } \\
\%\end{array}$ & $\begin{array}{l}\text { Shoot } \\
\text { length } \\
(\mathrm{cm})\end{array}$ & $\begin{array}{l}\text { Plant } \\
\text { spread } \\
(\mathrm{cm})\end{array}$ & $\begin{array}{l}\text { Girth of } \\
\text { seedling } \\
(\mathrm{mm})\end{array}$ & $\begin{array}{l}\text { Seedling } \\
\text { vigor index }\end{array}$ & $\begin{array}{l}\text { Seedling } \\
\text { length } \\
(\mathrm{cm})\end{array}$ & $\begin{array}{l}\text { Chlorophyll } \\
\text { content of } \\
\text { leaves }(\mathrm{mg} / \mathrm{g})\end{array}$ & $\begin{array}{c}\text { Surviva } \\
\%\end{array}$ \\
\hline $\mathbf{T}_{\mathbf{0}}$ & Control & 24.00 & 33.33 & 19.13 & 17.20 & 2.13 & 713.33 & 21.26 & 0.71 & 30.33 \\
\hline $\mathbf{T}_{1}$ & $\mathrm{GA}_{3} 100 \mathrm{ppm}$ & 23.00 & 40.33 & 19.46 & 17.76 & 3.26 & 876.33 & 21.60 & 0.92 & 37.00 \\
\hline $\mathbf{T}_{2}$ & $\mathrm{GA}_{3} 200 \mathrm{ppm}$ & 19.00 & 43.33 & 19.90 & 18.06 & 3.43 & 962.40 & 22.23 & 0.88 & 40.33 \\
\hline $\mathbf{T}_{3}$ & $\mathrm{GA}_{3} 300 \mathrm{ppm}$ & 16.66 & 48.33 & 21.03 & 19.60 & 4.43 & $1,135.43$ & 23.50 & 0.98 & 45.00 \\
\hline $\mathbf{T}_{4}$ & NAA 100 ppm & 20.33 & 59.23 & 21.26 & 19.13 & 4.13 & $1,099.93$ & 23.36 & 0.93 & 52.00 \\
\hline $\mathbf{T}_{5}$ & NAA 200 ppm & 18.66 & 52.66 & 22.03 & 18.86 & 3.63 & $1,259.93$ & 23.93 & 1.03 & 48.33 \\
\hline $\mathbf{T}_{6}$ & NAA 300 ppm & 20.33 & 62.33 & 22.56 & 21.16 & 3.76 & $1,491.10$ & 24.83 & 1.10 & 61.33 \\
\hline $\mathbf{T}_{7}$ & $\begin{array}{c}\text { Aspergillus }(10 \mathrm{ml} / 100 \mathrm{ml} \text { distilled } \\
\text { water })\end{array}$ & 22.66 & 57.33 & 21.60 & 21.56 & 3.90 & $1,482.73$ & 23.66 & 0.95 & 57.00 \\
\hline $\mathbf{T}_{8}$ & $\begin{array}{l}\text { Pseudomonas }(10 \mathrm{ml} / 100 \mathrm{ml} \text { distilled } \\
\text { water) }\end{array}$ & 17.33 & 65.00 & 23.23 & 22.53 & 4.33 & $1,652.33$ & 25.56 & 1.10 & 59.66 \\
\hline $\mathbf{T}_{9}$ & PSB $(10 \mathrm{ml} / 100 \mathrm{ml}$ distilled water $)$ & 17.33 & 47.33 & 22.46 & 22.93 & 4.76 & $1,647.47$ & 24.53 & 1.03 & 43.66 \\
\hline $\mathbf{T}_{10}$ & $\begin{array}{l}\text { Aspergillus }+ \text { Pseudomonas }(10 \mathrm{ml} \\
\text { each in } 100 \mathrm{ml} \text { distilled water })\end{array}$ & 19.66 & 60.66 & 24.46 & 23.23 & 4.16 & $1,428.39$ & 26.83 & 1.27 & 57.00 \\
\hline $\mathbf{T}_{11}$ & $\begin{array}{c}\text { Aspergillus + PSB (10ml each in } \\
100 \mathrm{ml} \text { distilled water) }\end{array}$ & 14.66 & 54.56 & 23.56 & 20.66 & 4.43 & $1,512.93$ & 25.70 & 1.11 & 55.66 \\
\hline $\mathbf{T}_{12}$ & $\begin{array}{c}\text { Pseudomonas + PSB (10ml each in } \\
100 \mathrm{ml} \text { distilled water) }\end{array}$ & 06.66 & 72.66 & 25.66 & 25.90 & 6.00 & $2,060.53$ & 28.40 & 1.54 & 69.00 \\
\hline \multirow[t]{4}{*}{$\mathbf{T}_{13}$} & $\begin{array}{c}\text { Aspergillus }+ \text { PSB }+ \text { Pseudomonas } \\
(10 \mathrm{ml} \text { each in } 100 \mathrm{ml} \text { distilled } \\
\text { water })\end{array}$ & 08.33 & 70.33 & 25.03 & 24.63 & 5.36 & $1,912.67$ & 27.16 & 1.393 & 66.66 \\
\hline & CD & 8.681 & 12.213 & 2.393 & 1.792 & 2.133 & 401.826 & 2.358 & 0.353 & 11.586 \\
\hline & SEd & 4.2 & 5.909 & 1.158 & 0.867 & 3.267 & 194.41 & 1.141 & 1.171 & 5.605 \\
\hline & F-Test & $\mathbf{S}$ & S & S & S & S & S & S & $\mathbf{S}$ & S \\
\hline
\end{tabular}


The growth promoting substance produced by PGPR have exerted a synergistic action and enhanced the growth promotion of Aonla. Pseudomonas spp. was reported to produce amino acids, salicylic acid and IAA which might have improved the plant growth and seedling vigour. (Sivamani and Gnanamanickam, 1988; O'Sullivan and O'Gara, 1992)

\section{Seedling length (shoots length + root length)}

The maximum seedling length was recorded in $\mathrm{T}_{12}$ [Pseudomonas fluorescens $+\mathrm{PSB}$ Rhodopseudomonas palustris $(10 \mathrm{ml}$ each in $100 \mathrm{ml}$ distilled water)] with $28.40 \mathrm{~cm}$ followed by $\mathrm{T}_{13}$ (Aspergillus niger $+\mathrm{PSB}$ Rhodopseudomonas palustris + Pseudomonas fluorescens $(10 \mathrm{ml}$ each in $100 \mathrm{ml}$ distilled water)] with $27.16 \mathrm{~cm}$ which were significantly superior over control with 21.26 cm length.

Plant growth promoting Rhizobacteria (PGPR) have environmental desirable capacities such as nitrogen-fixation, phosphate and potassium-solubilisation, which makes available for plant root to absorption and utilization of mineral nutrition, which leads to the seedling growth ( $\mathrm{Lu}$ and Huang, 2010), (Nihorimbere et al., 2011). IAA positively influences root growth and development, thereby enhancing nutrient uptake (Khalid et al., 2004).

\section{Chlorophyll content of leaves}

The maximum chlorophyll content was recorded in $\mathrm{T}_{12}$ [Pseudomonas fluorescens+ PSB Rhodopseudomonas palustris $(10 \mathrm{ml}$ each in $100 \mathrm{ml}$ distilled water)] with $1.54 \mathrm{mg} / \mathrm{g}$ of fresh seedling, followed by $\mathrm{T}_{13}$ [Aspergillus niger + PSB Rhodopseudomonas palustris + Pseudomonas fluorescens $(10 \mathrm{ml}$ each in 100 $\mathrm{ml}$ distilled water)] with $1.393 \mathrm{mg} / \mathrm{g}$ of fresh seedling which were significantly superior over $\mathrm{T}_{0}$ (control) with $0.713 \mathrm{mg} / \mathrm{g}$ of fresh seedling.

P. fluorescens rapidly utilizes seed and root exudates and produces a wide spectrum of bioactive metabolites. PSB is capable of fixing nitrogen for growth and its genes encode for protein that make up light harvesting complexes and photosynthetic reaction centers. The amount of PSB added promote the plant resistance against disease; increase the content of chlorophyll and seedling growth. Similar findings were observed by Ke et al., (2005) in cucumber, Jun-lin et al., (2012) in eggplant and Yali et al., (2014) in Chinese cabbage.

On the basis of results obtained, it is concluded that the treatment $\mathrm{T}_{12}$ [Pseudomonas fluorescens + PSB Rhodopseudomonas palustris $(10 \mathrm{ml}$ each in $100 \mathrm{ml}$ distilled water)] found to be best in terms of minimum day to germination (06.66 days), germination percentage $(72.66 \%)$, survival percentage $(69.00 \%)$, shoot length $(25.66 \mathrm{~cm})$, seedling length $(28.40 \mathrm{~cm})$, plant spread $(25.90 \mathrm{~cm})$, girth of seedling $(6.00 \mathrm{~mm})$, seedling vigor index (2060.53), and chlorophyll content of leaves $(1.54 \mathrm{mg} / \mathrm{g})$.

Application of plant growth regulators and biofertilizers in seed germination of Aonla has great impact on physiological processes in plants which are extensively and profitably used in horticultural crops. They are also used for increasing plant growth and protecting the nursery plants from several insect-pest and diseases.

\section{References}

Bais HP, Weir TL, Perry LG, Gilroy S, Vivanco JM (2006). The role of root exudates in rhizosphere interactions with plants and other organisms. Annu 
Rev. Plant Biol 57:233-266https: //doi.org/10.1146/annur ev.arpla nt.57.032905.105159.

Berendsen RL, Pieterse CM, Bakker PAHM (2012). The rhizosphere micro biome and plant health. Trends in Plant Science. 2012; 17:478-486.

Berg G, Eberl L, Hartmann A (2005). The rhizosphere as a reservoir for opportunistic human pathogenic bacteria. Environ Microbial 7:16731685https: //doi.org/10.1111/j.14622920.2005 .00891$.

Egamberdieva, Dilfuza (2007). The effect of plant growth promoting bacteria on growth and nutrient uptake of maize in two different soils. Applied Soil Ecology. $36 . \quad 184-189$. 10.1016/j.apsoil.2007.02.005.

Gholami, Ahmad \& Shahsavani, Shahin \& Nezarat, Somayeh. (2008).The Effect of Plant Growth Promoting Rhizobacteria (PGPR) on Germination, Seedling Growth and Yield of Maize. World Acad Sci Eng Technol. 49.

Gray, E.J. and Smith, Donald. (2005). Intracellular and extracellular PGPR: Commonalities and distinctions in the plant-bacterium signalling processes. Soil Biology and Biochemistry. 37. 395-412.

10.1016/j.soilbio.2004.08.030.

Harman GE, Howell CR, Viterbo A, Chet I, Lorito M (2004). Trichoderma speciesopportunistic, virulent plant symbioses. Nature Reviews. 2004; 2:43-56.

Junlin L, Yuping M, Lihua Z. (2012). Influence of Photosynthetic Bacteria to Greenhouse Eggplant Yield and Quality, Modern Agricultural Science and Technology, Index: S641.1; S626. CLC number S144; S641.1, Document code A, 2012. Article number 10075739, 11-0076-02.

Ke C, Guoying D, Bingbing F, Zhanfang Y. (2005). The applications of the photosynthetic bacteria on vegetable and wastewater treatment. Agriculture and Technology 2005-06, Index S642.2; X703. CLC number: S123, Document code: B, 2005.

Khalid, Azeem; Arshad, Muhammad; Shaharoona, Baby; Mahmood, Tariq. (2009). Plant Growth Promoting Rhizobacteria and Sustainable Agriculture. 10.1007/978-3-642-019791_7.

Kloepper JW, Leong J, Teintze M, Schroth MN (1980). Enhanced plant growth by siderophores produced by plant growth-promoting Rhizobacteria. Nature. 1980; 286:885-886.

Marx J. (2004). The roots of plant-microbe collaborations. Science. 2004; 304:234236.

Mendes R, Garbeva P, Raaijmakers JM (2013). The rhizosphere micro biome: significance of plant beneficial, plant pathogenic, and human pathogenic microorganisms. FEMS microbial Rev 37:634-663https:

//doi.org/10.1111/1574-6976.12028

Micallef SA, Shiaris MP, Colón-Carmona A (2009) Influence of Arabidopsis thaliana accessions on rhizobacterial communities and natural variation in root exudates. J Exp Bot 60:17291742https: //doi.org/10.1093/jxb/erp053.

Nehal M. Elekhtyar (2015).Efficiency of Pseudomonas fluorescens as Plant Growth-Promoting Rhizobacteria (PGPR) for the enhancement of Seedling Vigour, Nitrogen Uptake, Yield and Its Attributes of Rice (Oryza sativa L.). International Journal of Scientific Research in Agricultural Sciences, 2(Proceedings), pp. 057-067, 2015. http://www.ijsrpub.com/ijsras

Nihorimbere V, Ongena M, Smargiassi M, Thonart P. (2011). Beneficial effect of the rhizosphere microbial community 
for plant growth and health. Biotechnology, Agronomy and Society and Environment. 2011; 15(2):327-337.

O'Sullivan DJ, O'Gara F. (1992). Traits of fluorescent Pseudomonas spp. involved in suppression of plant root pathogens. Microbiological Review. 1992; 56(4):662-676.

Shen X, Hongbo Hu, Huasong Peng, Wei Wang, Xuehong Zhang (2013). Comparative genomic analysis of four representative plant growth-promoting Rhizobacteria in Pseudomonas. BMC Genomics. 2013; 14:271.

Sivamani, E., Gnanamanickam, S.S. (1998). Biological control ofFusarium oxysporum f.sp.cubense in banana by inoculation with Pseudomonas fluorescens. Plant Soil 107, 3-9 (1988). https://doi.org/10.1007/BF02371537

Son, A. R.; Hyun, Y.; Htoo, J. K.; Kim, B. G., (2014). Amino acid digestibility in copra expellers and palm kernel expellers by growing pigs. Anim. Feed
Sci. Technol., 187: 91-97

Van Loon LC, Bakker PAHM, Pieterse CMJ (1998). Systemic resistance induced by rhizosphere bacteria. Annu. Review. Phytopathology. 1998; 36:453-483.

Vinale F, Sivasithamparam K, Ghisalberti EL, Marra R, Woo SL (2008). Trichoderma-plant-pathogen interactions. Soil Biology and Biochemistry. 2008; 40:1-10.

Widnyana, I Ketut and Javandira, Cokorda. (2016). Activities Pseudomonas spp. and Bacillus sp. to Stimulate Germination and Seedling Growth of Tomato Plants. Agriculture and Agricultural Science Procedia. 9. 419423. 10.1016/j.aaspro.2016.02.158.

Yali L, Xiaofeng C, Lele X. (2014). Photosynthetic Bacteria's Effect on Growth and Quality of Non-heading Chinese cabbage, Chinese Horticulture abstracts 2014 no 8, Index: S634, 2014.

\section{How to cite this article:}

Vibha Kumari, Vijay Bahadur, Saket Mishra, Samir Ebson Topno and Deena Wilson. 2020. Effect of Phytohormones and Plant Growth Promoting Microorganisms on Germination and Plant Growth of Aonla (Emblica officinalis Gaertn.). Int.J.Curr.Microbiol.App.Sci. 9(11): 7683. doi: https://doi.org/10.20546/ijcmas.2020.911.008 